\title{
Police and thieves in the stadium: measuring the (multiple) effects of football matches on crime
}

Citation for published version (APA):

Marie, O. (2010). Police and thieves in the stadium: measuring the (multiple) effects of football matches on crime. Researchcentrum voor Onderwijs en Arbeidsmarkt, Faculteit der Economische Wetenschappen. ROA Research Memoranda No. 9 https://doi.org/10.26481/umaror.2010009

Document status and date:

Published: 01/01/2010

DOI:

10.26481/umaror.2010009

Document Version:

Publisher's PDF, also known as Version of record

\section{Please check the document version of this publication:}

- A submitted manuscript is the version of the article upon submission and before peer-review. There can be important differences between the submitted version and the official published version of record.

People interested in the research are advised to contact the author for the final version of the publication, or visit the DOI to the publisher's website.

- The final author version and the galley proof are versions of the publication after peer review.

- The final published version features the final layout of the paper including the volume, issue and page numbers.

Link to publication

\footnotetext{
General rights rights.

- You may freely distribute the URL identifying the publication in the public portal. please follow below link for the End User Agreement:

www.umlib.nl/taverne-license

Take down policy

If you believe that this document breaches copyright please contact us at:

repository@maastrichtuniversity.nl

providing details and we will investigate your claim.
}

Copyright and moral rights for the publications made accessible in the public portal are retained by the authors and/or other copyright owners and it is a condition of accessing publications that users recognise and abide by the legal requirements associated with these

- Users may download and print one copy of any publication from the public portal for the purpose of private study or research.

- You may not further distribute the material or use it for any profit-making activity or commercial gain

If the publication is distributed under the terms of Article $25 \mathrm{fa}$ of the Dutch Copyright Act, indicated by the "Taverne" license above, 
Police and Thieves in the Stadium: Measuring the (Multiple) Effects of Football Matches on Crime

Olivier Marie

\section{ROA Research Memorandum}

ROA-RM-2010/9

Research Centre for Education and the Labour Market Maastricht University

P.O. Box 616, 6200 MD Maastricht, The Netherlands

$\mathrm{T}+31433883647 \mathrm{~F}+31433884914$

secretary-roa-sbe@maastrichtuniversity.nl www.roa.n 


\title{
Police and Thieves in the Stadium: Measuring the (Multiple) Effects of Football Matches on Crime
}

\author{
Olivier Marie
}

ROA-RM-2010/9*

July 2010

Research Centre for Education and the Labour Market Maastricht University

P.O. Box 616, 6200 MD Maastricht, The Netherlands

$\mathrm{T}+31433883647 \mathrm{~F}+31433884914$

secretary-roa-sbe@maastrichtuniversity.nl

www.roa.nl

* The ROA Research Memorandum Series was created in order to make research results available for discussion, before those results are submitted for publication in journals. 


\title{
Abstract \\ Police and Thieves in the Stadium: \\ Measuring the (Multiple) Effects of Football Matches on Crime**
}

During large sporting events criminal behaviour may impact on criminal behaviour via three main channels: (i) fan concentration, (ii) self incapacitation, and (iii) police displacement. In this paper I exploit information on football (soccer) matches for nine London teams linked to detailed recorded crime data at the area level to empirically estimate these different effects. My findings show that only property crime significantly increases in the communities hosting football matches but that they experience no changes in violent offences. These results are robust to controlling for a large number of game type and outcome characteristics. There is no evidence of temporal displacement of criminal activity. Our conceptual model suggests that the away game attendance effect on crime is due to voluntary incapacitation of potential offenders. I argue that the police displacement effect of hosting a match increases property crime by 7 percentage point for every extra 10,000 supporters.

\author{
Olivier Marie \\ ROA \\ Maastricht University \\ P.O. Box 616 \\ 6200 MD Maastricht \\ The Netherlands \\ o.marie@maastrichtuniversity.nl
}

\footnotetext{
** I would like to thank Arnaud Chevalier, Thomas Dohmen, Stephen Machin, Jonathan Wadsworth and audiences at seminars at the London School of Economics, the University of Surrey, Maastricht University, the 2010 RES Conference, the 2010 ESPE Conference, and the 2010 EALE/SOLE Conference for useful discussion and comments. I am extremely grateful to Mark Baber from the Association of Football Statisticians (AFS) for his help in gathering the football match data.
} 
"If I were involved in criminality of a more sophisticated kind... would I not work on the assumption that the police will be fully occupied in a particular city - it will not be difficult to find out when these premiership games are being played - and I could go about my unlawful business?"

Question by Mr David Winnick MP to the House of Commons Home Affairs Committee “The Cost of Policing Football”, 16 June 2009.

\section{Introduction}

The impact on local crime rates of hosting large sporting events is complex. It is not limited to the documented increases in violence resulting from (i) the concentration of hostile fans. One must also consider the impact on criminal behaviour of: (ii) the displacement of police personnel sent to monitor the event and (iii) the voluntary incapacitation of a substantial number of individuals who are assisting it. Still, most research on this issue has focused on documenting and studying aggressive fan behaviour. This literature has attempted to explain the reasons for the recurring problem of crowd violence during sporting events (see review by Young 2002) with special attention to the phenomenon of hooliganism associated with European football ${ }^{1}$ (Dunning et al 1988) which reached its peak in the 1980s. One aim of this research will be to investigate if a similar relationship can be observed during football matches because of the geographical concentration of rival fans. But we are also interested in other possible indirect impacts that hosting sporting events could have on local crime and especially property and other nonviolent offences. The first effect to consider stems from the possible displacement of law enforcement personnel sent to police a game which could leave other areas under-protected. Another effect is that of some potential offender being voluntarily incapacitated among the large numbers of individuals busy assisting a game.

In this paper we estimate the overall impact of hosting a sporting event on local crime taking into account all these possible impacts on offending behaviour. Because the relationship described is relatively complex, we first develop a conceptual framework to disentangle the different effects through which match attendance and police displacement affect crime. While it is difficult to exactly estimate the

\footnotetext{
${ }^{1}$ Throughout this paper we will refer to football as what is known in the US as soccer. We will specify 'American' when we mention the other form of the game.
} 
respective impact of concentration, displacement, and self-incapacitation on crime, we can get an idea of their relative influence by making some simple assumptions on their likely impact on various types of offences for home and away matches. This strategy of differentiating between property and violent crimes is inspired by the work of Jacobs and Legren (2003) on the impact of school attendance on juvenile offending. They found that concentration of youths when school is in session increased violent crime but also led to drops in property crime they attribute to a self incapacitation effect. With sporting events we can assume that offending behaviour could be affected in a relatively similar manner. We can also consider the difference in impact of the local team playing at home and away since police displacement should only occur when the event is hosted in the area. Finally we can treat each match according to the size of the fan population they are likely to attract. When the game is being played away this should only have an impact on the potential numbers of offenders incapacitated during the game. As Dahl and Della Vigna (2009) point out in their study of the impact of violent movies on violent crime, the size of an audience should matter more for criminal behaviour if there is self selection into attendance. We argue that football fans are a non-random sample of the population with demographic characteristics making them more prone to be potential offenders. Combining all these assumptions we can identify each of the three channels through which sporting events could impact on crime separately.

We gathered information on the home and away matches of the nine major London football teams with stadiums located in seven different boroughs of the city. We have matched this data to hourly recorded crime from the Metropolitan Crime Statistics System (MCSS) covering 31 London boroughs $^{2}$ that is available from October 1994 to March 1997. We divide each day into four six hour windows starting at 6 A.M.. Almost all matches start either at 3 P.M. or 8 P.M. and we label the period during a game accordingly as the second or third six hour window of the day. To identify a match effect on local criminal activity we can exploit the variation in location and timing of both home and away games. Since we have extensive information on each game, we will focus our attention on the impact of the large variations in attendance for our identification, controlling for weather conditions and

\footnotetext{
${ }^{2}$ There are 32 boroughs or Local Authorities in London but one of them, Sutton, did not properly record crime on the central system during this period. Fortunately for us, it does not host any important football team and also is on the periphery of the city.
} 
whether the game is played on a holiday. We also include a whole set of controls to net out the possible influence of other matches taking place at the same time as well as the distance of each borough to the stadium hosting a home game and the distance of each away match. We check how the results are affected by controlling for the type of game being played and the outcome of each match as these factors could influence the three effects we seek to identify differently. Finally we consider the issue of possible temporal displacement of criminal activity before and after games. This is important for two reason: first crime rates have been shown to be serially correlated (Jacobs et al 2007) and decond, post event criminal activity of an audience could change for psychological reasons (Dahl and Della Vigna 2009). In all the models we estimate we include borough, hour window, day of the week, month, and football season fixed effects to account for unobserved time- and location-specific factors that may be correlated with matches and crime.

We find that the level of property crime increases by roughly 4 percent and falls by about 3 percent for every extra 10,000 supporters attending respectively a home and an away game. According to our conceptual framework we conclude that displacement of police is the factor that contributes most to the rise in property crime, likely because opportunistic offenders in the under protected areas of the borough take advantage of the smaller detection probability. We also conclude that voluntary incapacitation can explain the drop in criminal activity observed when attendance to away matches increases. We find no measureable impact on violent crime in the local community except during a derby match (i.e. when London teams play each other). This suggests some effect of concentration during those matches which are reputedly the ones with the highest levels of animosity between rival fans. As for displacement of crime, there are some signs that violence increases in the period after home games with attendance. This is again consistent with some level of hooligan behaviour between opposing fans after games. We then consider the difference in coefficients between home and away attendance on crime for up to 12 time periods before and after a match. We see then that only differences in property crime with changes in attendance are statistically significant. This leads us to downplay the importance of temporal displacement resulting from sporting events.

Our overall conclusion is therefore that, assuming that voluntary incapacitation has a relatively similar impact during home and away games, the displacement of police forces during football matches increases property crime by almost 7 percentage 
points for every extra 10,000 fans attending a game. This is in line with a growing body of evidence that police presence has an important effect on reducing crime. It also raises important issues of the negative impact of policing of private sporting events at the cost of the local communities wellbeing. Also it demonstrates the importance of considering all the direct and indirect channels which may influence crime when investigating such issues.

The remainder of the paper is structured as follows. Section I presents a conceptual framework for understanding and identifying the match-crime relationship. Section II describes the data used in this analysis. Section III presents the results and Section IV concludes.

\section{Understanding and Identifying the Match-Crime Relationship}

\section{A - Conceptual Framework}

There are three channels through which we expect sporting events to influence crime in the local community: concentration, displacement, and incapacitation. We describe in detail each of their likely respective impact below.

\section{Concentration}

Concentration is perhaps the channel that first comes to mind, as is evident by the enormous amount of anecdotal evidence. The geographical concentration of fans from teams with long standing histories of rivalry is likely to increase the number of volatile interaction among them. In its most extreme form this can lead to the levels of hooligan violence observed during European football matches in the 1980's ${ }^{3}$. More generally we expect that concentration could, on average, increase the incidence of violent offences in the communities which are hosting a home match. When games are played away, it is on the contrary unlikely that concentration will affect crime in the areas where the teams come from.

Note here that we are assuming no impact on property crime levels of concentration. This is perhaps a strong assumption since it is possible that matches

\footnotetext{
${ }^{3}$ During the 1985 European Cup Final between Juventus and Liverpool, 39 fans were killed and a further 600 were injured after the attack by supporters of the English club. British teams were then banned for five years to participate in any European competitions as punishment for the violent behaviour of their fans. This did not prevent the worst stadium related disaster in England four years later, the Hillsborough Disaster, where 96 football fans died as a result of unruly crowd behaviour and poor policing.
} 
facilitate the coordination of crime among fans including property offences. This could reveal itself in the form of higher levels of thefts after matches which were planned during the event. We do not observe such an effect and argue as Jacob and Legren (2003) in their study of school attendance and juvenile crime that concentration is likely to only have an impact on violent offences. In the context of large sporting events the potential numbers of violent interactions will increase with attendance levels. It could also depend on a game’s outcome (e.g. upset loss) which may affect the emotional state of fans to a point of modifying their gain-loss utility perception of participation in violence ${ }^{4}$. This may also be influenced by the level of rivalry between the teams which may further increase the potential for unruly crowd behaviour.

We can argue that these parameters will be taken into account when local authorities decide the level of police personnel to deploy around stadiums during each home game. This leads us to consider the possible impact of police displacement during sporting events on local crime activity.

\section{Displacement}

There is a growing literature looking at the police-crime relationship using terrorism related events since they sometimes induce a surge in police presence in particular locations (Di Tella and Schargrodsky 2004 and Draca et al 2008). Exploiting the resulting unexpected displacement in law enforcement personnel is an interesting strategy to measure the impact the police may have on criminal activity. In the case of football matches in England there is also a large increase in police presence around a particular location: the stadiums. However this increase is not the result of unexpected consequences such as a terrorist attack. Consequently one could assume that with proper planning the effect of concentrating police at the stadium should be minimal, and displacement in the area could be avoided.

\footnotetext{
4 Emotions on decision making has been extensively studied by psychologists and behavioural economists (e.g. Lowenstein 2000). Recent research by Card and Dahl (2009) investigates the impact of negative emotional cues from unexpected losses of a local American football team on domestic violence rates. They find that upset losses for the home team lead to an 8 percent increase in reports of male-on-female in the home to the police just after the match. We do not investigate domestic violence in this paper because of data limitations but believe the same emotional cue mechanism may explain possible violent encounters at sporting events. Indeed, in a recent paper Rees and Schnepel (2009) observed that local crime rates for a number of violence related offences were affected by upset losses (and wins) when the area is hosting an American college football game.
} 
However, there is evidence of a substantial amount of displacement occurring during matches. A report commissioned by the Metropolitan Police Authority on the impact of policing football games in London concluded that: "On an average Saturday, 500 officers are lost to their communities policing football matches throughout the MPA...Football costs the MPA £7.4M in police staffing alone” (MPA 2003). These estimated 500 officers represent about 7 percent of the police manpower working in London on an average Saturday being deployed to monitor football matches instead of their regular duties ${ }^{5}$. This is a relatively high level of a regular displacement considering that it compares to for example the exceptional 34 percent local surge in police after the terrorist attacks of July 72005 in London (Draca et al 2008) $)^{6}$.

The MPA report also gives evidence on the large difference in the cost in terms of number of officers deployed at matches depending on the police risk classification of the game played. These costs almost double when the risk increases with the expected level of attendance at a game and the type of match which will be played. We exploit the variation in crowd attendance at football matches as a proxy for the level of police displacement and the type of game played, especially competitions, since policing strategy cannot in theory be planned as accurately for those matches since they only occur with a win from the local team. Note that displacement only occurs during home games and that it could equally affect violent and property crime in the under protected areas of the boroughs hosting those matches

\section{Incapacitation}

Incapacitation is the general term used to express that individuals who are incarcerated or otherwise monitored cannot commit crimes in the community. More recently this definition has expended to other activities in which potential offenders engage more or less voluntarily keeping them from committing crimes. The impact of

\footnotetext{
${ }^{5}$ On an average Saturday all the police force in London work about 60,000 hours. This number divided by an 8 hour working day gives 7,500 officers $(500 / 7,500=0.066)$

${ }^{6}$ The fact that the police displacement caused is not due to an unexpected shock may be actually be beneficial to our analysis. This is because there is reason to believe that severe unforeseen events such as terror attacks which trigger changes in policing, may at the same time change the economic behaviour of individuals sharply in the short run (Bloom 2009), and likely also affect criminal behaviour. Regular displacement from sporting events should not suffer from this problem of correlated shock for our identification strategy. However one important effect which may change the behaviour of potential criminals is if they are busy assisting a match and consequently voluntarily incapacitated.
} 
self-incapacitation on offending behaviour has been investigated in the context of school attendance and juvenile crime (Jacob and Lefgren 2003) and violent movie frequentation and the incidence of violence (Dahl and Della Vigna 2009). In both cases the authors point out that these activities are undertaken by sub-samples of the population which have relatively high propensities of committing crime: the young and the potentially violent. Can we argue that the same selection is occurring for individuals choosing to attend football matches?

There is little information on who football fans who attend games are apart for some basic demographic characteristics. Still, one of the most widely documented factor explaining the probability of individuals' criminal behaviour is linked to their gender and age profile (Hirshi and Gottferdson 1983, Hansen 2003). In the UK arrest data shows that 85 percent of arrested offenders are male and 80 percent are under 30 years old. Surveys of English football supporters (FA Premier League Fan Survey 1994-1997) show that over 50 percent of them are under 30 years of age and nine out of ten are male. This is evidence of the strong demographic similarities between the football fan and the crime committing population. This does not imply that supporters are systematically potential offenders It suggests that as the attendance and importance of a game grows it is increasingly possible that it will incapacitate certain individuals which would have otherwise been involved in criminal activity.

We assume here that voluntary incapacitation will similarly impact on property and violent crime in a similar way. More importantly we argue that incapacitation influences criminal behaviour during both home and away games. This is supported by the afore mentioned fan surveys which show that fans attempt to travel to as many away games as possible, or will at least watch the television broadcast of the match. One other important characteristic of football fans is that two thirds of them report that they are born locally (within 20 miles of where team plays). This is important: if we want to attribute changes in borough crime rates to incapacitation of potential local criminals, matches must attract fans who also reside in the area. To assess the incapacitation impact of a match we exploit the variation in attendance levels to each game, which captures the variation in the degree of incapacitation.

\section{B - Identification Strategy}

We summarise the impact of the three potential channels - concentration, displacement, and incapacitation - through which sporting events potentially affect 
crime in Figure 1. The direction of each of the effects sporting events may have on crime is represented by type of crime and home or away game. This depiction of the conceptual framework makes it clear that a decrease in property or violent crime during an away game can be attributed to some level of incapacitation. Signs of increased property criminal activity during a home game would be interpreted as the effect of police displacement being stronger than the incapacitation effect. An estimate of the net displacement effect on property crime could be consequently generated by comparing the impact of home and away games on such offences. Finally, a measure of the impact of concentration could be obtained by comparing the change in property and violent crimes during home games.

We return later to the interpretation of separate estimates for each of the effects we are interested in. First we present the simple model we will use to identify the match-crime relationship:

$$
\text { Crime }_{a t}=\alpha_{a}+\delta_{1} \text { Home }_{a t}+\beta_{1} \text {HomeAtt }_{a t}+\delta_{2} \text { Away }_{a t}+\beta_{2} \text { AwayAtt }_{a t}+u_{a t}
$$

where crime is a measure of criminal activity (property or violent) at time $t$ in area $a$. $\alpha$ is an area level fixed effect. Home and Away are binary variable which take the value one or zero if the team from area $a$ is respectively playing a match at home or away. HomeAtt and AwayAtt represent the corresponding attendance levels to each of these matches. The $\delta$ coefficients will therefore capture the home and away match effects in the boroughs concerned. Our real interest lies in the identification of the $\beta$ coefficients which will be estimates of the direction of the variations in attendance on the direction of the effects summarised in Figure 1.

To improve our estimation of the match-crime relationship we must consider a number of other factors which may influence game attendance and offending simultaneously. The first obvious candidate is the weather which has been proven to change crime patterns (Jacobs et al 2007) and is also likely to have an impact on match attendance. We therefore include weather controls in our model measuring daily temperatures and rain falls. The day and the hour at which a match is played could also be important. Crime is not evenly distributed during the day and across days of the week. The fans attending afternoon or evening games may also be different and this may change from one season to the next depending on the successes of each team. To attempt and capture all these concerns we include borough*period of the day*day of the week*month*season fixed effects in our models. Finally our first 
model should include a holiday indicator since such days may also lead to changes in attendance and crime patterns simultaneously.

There are two other factors which could influence our estimation strategy in light of the conceptual framework we have developed. First it is important to note that there can be more than one home or away game being played by each of the teams we consider. This could have an impact on the levels of police displacement and voluntary incapacitation that go beyond just the match and attendances we measure for a single borough. We therefore control in our model for the number of other home or away games taking place in other areas and the level of attendance these matches attract. Second we have to consider that the impact a match in one area will have on other areas will partly depend on the distance between the two entities. We consequently include an indicator of the distance of each borough to the one where the local team is playing a home or an away game to capture this effect. Related to this we may be concerned that the attendance to away games will differ depending on the distance of the host team. We therefore also include distance in kilometres to the away game in the models we will estimate for various crime categories.

A final important set of factors which could influence the match-crime relationship will depend on the type of match and outcome of the game that is being played. Rees and Schnepel (2008) and Card and Dahl (2009) found for example that when the local team suffers an 'upset' loss it further increases the incidence of respectively violent offences and domestic violence. We will therefore control for the game having been lost when it was expected to be won to test this hypothesis in our context. We also include controls for the goal difference, number of yellow and red cards received during the game, and the match being a derby (one London team against another). We argue that these characteristics of a football match could incite changes in fan behaviour not captured by the size of the crowd attending a game. Theoretically they should mostly impact on violent crime if supporters are psychologically affected by the success or defeat of their team or the level of conflict between players they have witnessed during the game. Rivalries are notoriously the highest between teams from the same city and this heightened potential for volatile interactions will be captured by our derby dummy. A last element of interest for our identification is to see if there is a differential impact of matches on crime if the games were scheduled on short notice. This would be reflected by the impact on local crime of football matches changing as teams move further up a knockout competition 
. We test this assumption by including at which round of a competition the game being played belongs.

\section{C - Temporal Displacement}

The extensive modelling strategy we describe should enable us to reliably estimate the impact of football matches on local area crime. Still we must concern ourselves with the possibility that any impact we may find is simply the result of the temporal displacement of criminal activity. This is why we should carefully consider how crime incidence changes before and after a game takes place. This is especially important in the context of analysing the behaviour of football fans as rival supporters may prefer to engage in violent behaviour before or after matches. There are two reasons for this. First they may choose to focus on the sport during the match or in other words prefer voluntary incapacitation over engaging in violent interaction at that time. Also the risks of detection are the highest in the vicinity of stadiums during the match because of the large number of police forces deployed there. Rival fans may therefore decide to settle scores before or after a game for these two reasons. This would impact on the measured levels of violent crime observed before or after a home game. We will therefore estimate lagged and forward models which include all the controls mentioned above. Controlling for type and outcome of matches is important since the psychological factors we discussed above could influence criminal behaviour in the short run.

We will also investigate how property crime is affected in the time periods surrounding matches. Let us make the assumption that individuals choose to make an optimal number of crime, for example one, each day for financial reasons. If this offender is voluntarily incapacitated during a match because he is following it, he/she will decide to commit the property crime at another moment during that day. On the other hand if this criminal is an opportunistic one, he/she will choose to commit the property offence while police are displaced during a game. The first example would increase property crime before or after matches while the second one would reduce this type of criminal activity outside the game period. The main argument here is that the aggregate number of property crimes in a borough would then not change during the entire day. The game effect would only distort the time at which they occur. Another concern is the possibility of offenders coordinating future crimes while they 
are together at matches. In this case the quantity of offences would increase in the periods following games more than by the normal daily aggregated level of crime.

To investigate this possibility we also extend our period of investigation to plus and minus twelve six hour periods before and after games. This corresponds to the three days around matches which is logical time choice if we assume optimal criminal decisions being made on a weekly basis. We will present the difference between home and away attendance coefficients $\left(\beta_{1}-\beta_{2}\right)$ for all 25 periods to consider how matches distort criminal activity temporally in the light of our original conceptual framework.

\section{Data}

\section{A- Football Data}

We have collected information for all matches for the nine major London football teams from October 1994 to March 1997 with the help of the Association of Football Statistician. The teams are Arsenal, Charlton Athletics, Chelsea, Crystal Palace, Millwall, Queens Park Rangers, Tottenham Hotspurs, West Ham United, and Wimbledon. As can be seen in Figure 2, these teams have their home stadiums located in seven of the 31 boroughs of London. The teams located in the same boroughs always alternate home and away matches when playing at the same time which therefore does not pose problems for our modelling strategy ${ }^{7}$. We have a total of 1,147 games played by our nine London teams during this time period. We drop from the data days which fall out of the football season which runs from mid-August to mid-May.

Figure 3 shows the levels of attendance for each of the nine London teams with the top panel for home games and the bottom panel for away matches.. The average attendance level across team for this period is roughly 20,000 spectators for both types of games. However the Figures show how this varies greatly between teams and also from one match to the next. This is a very important feature for our identification strategy which relies on changes in attendance levels across time.

For each match we have detailed information on its type and outcome. We have the final score and goal difference for each match. We use the predicted outcome of each game by bookmakers (based on the Elo ratings system) to classify a game was an

\footnotetext{
${ }^{7}$ The model exploits the difference in attendance levels to home and away matches when both happen simultaneously for teams located in the same borough.
} 
upset loss or not ${ }^{8}$. For the matches which are competitions - i.e. not regular schedule games part of the national championship -, we have up to ten rounds to reach a final. We gathered information on the number of yellow and red cards handed out by the referee during each game. We know the location of away matches and use it to estimate the distance fans have to travel.

Table 1 reports the main summary statistics for these matches and shows an almost even distribution between home and away games in our sample. Although most games are played on Saturday afternoon the distribution is still relatively dispersed with for example 17 percent of matches on Wednesday evenings. The distribution is also quite evenly distributed across borrows where the major London football teams are located. Finally, a significant number of matches are derbies (7\%), competitions (17\%), and upset losses (5\%) which will be useful for our identification of the various effects these games could have on crime.

\section{B - Crime Data}

The football data was matched at the borough level to hourly recorded crime from the Metropolitan Criminal Statistics System (MCSS). This database includes on all crimes recorded in London by the police including information on the borough where offences took place and the estimated time at which they were committed. We can differentiate between property (burglaries, theft and handling of stolen goods, and criminal damage) and violent (violence against the person, sexual offences, and robberies) crime categories. We generate from the timing of crime information four equal six hours periods which run from 6 A.M. one day to the same hour on the following day $^{9}$. This is the most geographically detailed and high frequency crime data available in the UK to our knowledge.

\footnotetext{
${ }^{8}$ I would like to thank Bill Hunter from Mables-Tables.com for providing me with the Elo ratings data for each game. The basic idea behind this rating system is that as football matches are played over a season individual points totals are updated for each team depending upon match results. These points are used as the basis for match predictions and 'upset losses' will be defined as the home team losing (at a home or away) when the advantage in terms of Elo ratings was $>100$.

${ }^{9}$ The six hours window was chosen because this is the time officers are assigned to a home match and would therefore account for the appropriate period to account for within borough police displacement (House of Commons Home Affairs Committee, 2009). A football game lasts more or less two hours
} 
Table 2 reports the mean number of crimes recorded for different categories in the seven boroughs where football teams are located. It shows the statistic by period of the day and whether there was no game, a home game, or an away game in the borough. We can see that most crimes recorded are property crimes and that the levels are much higher for this category during the afternoon rather than the evening hours. The large standard deviations suggest large variations in the number of recorded offences across periods and areas. It is therefore not possible by looking at the Table to begin and stipulate if any type of crime is higher or lower during home or away matches. The over-dispersion of the number of crimes committed is a common feature of area level crime data at high frequency. From an econometric standpoint, it is important to use an estimation strategy that takes into account the nature of the data.

\section{C - Estimation Strategy}

While the simplest methodology is to estimate ordinary least-squares (OLS) models using the number of recorded crime, this strategy has several problems. Because criminal incidents are positively skewed, it is common to transform the data using log or log rates. However, because we are using six-hourly data for individual boroughs there are a non-trivial number of zeros - particularly when focusing on individual crime categories ${ }^{10}-$ in the data complicating the use of log rates. In order to address this concern we use a negative binomial regression model. It is a generalisation of the Poisson regression model that allows for the variance of the outcome measure to differ from the mean, making it appropriate for count data with over-dispersion. In order to accommodate the fixed effects we have introduced in our model, we used the fixed effects negative binomial developed by Hausman et al (1984). The coefficients we will estimate represent the effects of the independent variables on the log of the mean incidence and can therefore be interpreted as the percentage effect of the independent variables on crime.

There are only seven boroughs in our data which will be identifying game attendance 'treatment' as their local teams are playing home or away. This raises the question of the validity of using the other 24 London areas which do not have football

and the six hours window would also capture the two hours before and after a match when a potential offender could be incapacitated with pre and post match activities.

10 There were only 3.4 percent hour-window/borough cells when no property crimes were recorded but almost 37.5 percent with no violent crimes reported. Certain offence sub-categories have extremely few incidents reported and therefore a very large number of zeros (e.g. 88.9 percent for criminal damage and 92.7 percent for sexual offences). 
teams for our analysis? There are two reasons why it seems appropriate to keep all the available boroughs in our analysis. The first is simply that although the areas with no teams will not contribute to the identification of our estimates of the game attendance coefficients, they do help us to estimate the other covariates with greater precision. The fixed effect nature of our models also should guarantee that we are estimating match impacts on crime within borough that will not be affected by using the areas with no local football teams.

The second reason to use all the 31 boroughs of London for our analysis is our concern with possible spatial displacement issues. There is a possibility that areas without a local team may be affected by match attendance in other boroughs. Fan concentration, police displacement, and voluntary incapacitation may impact on the criminal activity of these areas although in a way which is difficult to conceptually describe. We assume that if there is such an indirect impact in place it should be stronger for boroughs closer rather than further away from treated areas. This is why we have included controls for measures distances to boroughs with home and away games in our models which should capture possible spatial displacement effects of the match-crime relationship. For these reasons we believe that using all the boroughs of London for our analysis to obtain the most precise estimates possible.

\section{Results}

The first results in column (1) of Table 3 present negative binomial regression estimates with fixed effects, holiday and weather controls in which the dependent variable is the total number of recorded crimes. We build up from this model and add dummies for number of other games, total attendance level at those games, distance measures for each borough to areas hosting a match and distance to away games played by a local team. The resulting impact on all crimes is reported in column (4) and we find positive and significant home game and home attendance effects. The coefficient on the home game dummy captures the raw impact of hosting a match on the crime rate in a borough. Our identification stems from the variations in attendance and we see in column (4) that an extra 10,000 fans at a home game lead to a 4 percent increase in crime. We find so far no impact of away attendance levels on criminal activity. The importance of considering different offence categories is highlighted in columns (5) and (6) which report results for property and violent crimes. We find that all the match effect on crime we observe comes from changes in the recorded property 
offences. There is now a significant decrease in the numbers of property crimes committed when a local team is playing away suggesting some level of incapacitation as attendance to those games grows.

We consider more detailed crime categories in the results reported in Table 4. The results show that all the home and away game effects on property offences stems from the number of thefts committed during matches. There is no sign of changes in burglaries and importantly, criminal damage, which could be argued to be an atypical property crime that may increase as a result of the concentration effect. Also we still find no evidence of changes in violent crimes apart from the home game 'intercept' is now marginally significant. The theft category is mostly composed of thefts from and of motor vehicles ${ }^{11}$, thefts from shops and of pedal cycles. We can reasonably argue that these types of crimes are the most attractive to opportunistic offenders for financial gains. We therefore interpret the strong coefficients associated with this category of offences during home and away attendance as a sign that a combination of displacement and voluntary incapacitation is at play in the match-crime relationship.

Results from models which include a large number of information on matches outcome and type are reported in Table 5. We still observe our main finding of increases (decreases) of property crimes as attendance to home (away) games grows. However all the other game controls we include do not appear to change the levels of property offences committed during matches. This is also what we find for almost all the match outcome and type variables we add to the model for violent crime. We are more surprised by this result since we assumed many of these match outcome controls could have psychological influence over fan violent behaviour. The only interesting result here is a marginally significant notable increase in violence when an area is hosting a derby game. This suggests that concentration could play a role in increasing the number of violent interactions but only when the level of rivalry between opposing fans is high.

We now turn to considerations of possible temporal displacement of criminal activity in Tables 6.1 and 6.2. These tables report results from the same model as Table 5 for respectively property and violent crime for the six-hour periods before and

\footnotetext{
${ }^{11}$ We may worry that the potential supply of motor vehicles that can be stolen increases during home matches with the number of fans driving to the stadium. However, almost all the stadiums in our sample have adjoined car park facilities for fans which are part of the area patrolled by the police during games (the stadium 'footprint'). Also, all the teams are located in high density urban areas where the number of motor vehicles parked is certainly almost at maximum capacity which explains why most fans are advised and choose to travel to stadiums by public transport whenever possible.
} 
after each game. Table 6.2 shows that in this time window there does not appear to be any game attendance impact on property crimes. This would confirm that this type of criminal activity is not temporally displaced during the day but increases and decreases in absolute terms during home and away games. The picture for violent crime is different and the results are reported in Table 6.2. We find a marginally statistically significant increase in violent crime of 10 percent for every 10,000 extra fans after home matches in the host community. This is again a net increase over the day as we did not observe a matching decrease in crime over the other time periods. This is in line with the findings of Rees and Schnepel (2008) on the increase of violent offences experienced by the host community of sporting events. Our approach however suggests that it is important to distinguish between criminal behaviour effects during and after games. The voluntary incapacitation of potential offenders during matches ends after a game and appears to leave way for the violent encounters predicted by the concentration effect.

Limiting possible temporal displacement to only the short time window around a match may not capture the real distorting impact of a match. Jacobs et al (2007) for example showed that extreme weather shocks inversely displace crime in the following week. We therefore consider the possibility of a match effect up to 12 periods before and after games. The conceptual framework we designed to identify the match-crime relationship suggests that we compare the home and away game effects (Figure 1). We compute estimates of the difference in attendance coefficients $\left(\beta_{1}-\beta_{2}\right)$ from the model used in Table 5 for the 25 six-hour periods of interest. The estimated coefficients from this exercise are reported with +/- two standard errors in Figures 4.1 for property and 4.2 for violent crimes. The difference in game attendance effect during a match is at 0 on the axis with preceding and following time periods going from -12 to +12 . We find that the estimated effect is only statistically significant for property offences at the time when a match is taking place. The lack of any other effect identified for the difference of the home and game attendance coefficients leads us to several conclusions. First there appears not to be any noticeable temporal displacement of property or violent offence as a result of football matches. Second the observed increase in violence just after home matches is not precisely estimated enough to be significant. Finally the main finding from this research remains the important estimated increases in local property crime resulting from hosting large sporting events. 
Following our conceptual framework, we conclude that the principal explanation for this increase lies in the displacement of police forces during matches. The importance of voluntary incapacitation effect during matches is estimated from the negative coefficient of away attendance at -.003. By assuming a relatively similar level of incapacitation per home supporters, we are able to identify the net effect of police displacement. This is equivalent to the $\left(\beta_{1}-\beta_{2}\right)$ coefficient at period zero in Table 3.1 which is equal to -.007 with an associated standard error of .002. It means that property crime increases by 7 percent in a borough hosting a home game for every 10,000 extra fans attending and this is mainly of result of the displacement of law enforcement personnel policing the event. In absolute term this represents an extra 1.5 property crimes committed in a borough hosting a match during the six-hour period around the game.

\section{Conclusion}

We show in this paper that the impact large sporting events may have on criminal activity is more complex than the simple effect they could have on the violent behaviour of fans. We develop a conceptual framework to understand the matchcrime relationship which considers all the direct and indirect effects sporting events may have on offending behaviour. We describe three possible channels which are the geographical concentration of rival fans, the displacement of police personnel, and the voluntary incapacitation of potential offenders. Making simple assumptions we are able to determine the likely impact of each of these effects on local area crime during home and away games on property and violent crime. We the attempt to identify them separately by exploiting the variation in attendance to games from nine London teams located in seven different boroughs of the city.

Perhaps surprisingly, considering the amount of anecdotal evidence on the aggressive behaviour, we do not uncover any effect of football matches on area violent crime. There is however some evidence that the number of violent interactions is more frequent when the rivalry between opposite supporters is higher. The results also suggest that if the concentration effect is responsible for increases in violent crime, it is only in the hours after the game is over. This could be explained by the displacement and incapacitation effects only impacting on criminal behaviour during matches. However this evidence is relatively weak and we do not believe that football matches in London contribute to substantial changes in violent behaviour. 
The main finding of this research is that home game attendance significantly increases property crime in the borough hosting the event. On the contrary when teams are playing away, an inverse relationship is observed with property crime dropping as away attendance increases. We find no evidence of inter-temporal substitution of property crime even after extending the sample period of analysis to up to three days before and after the event. We calculate that voluntary incapacitation is responsible of a drop of 3 percent of the incidence of property crimes in a team home borough for every extra 10,000 fans attending an away match. Using this estimate we are able to evaluate a net police displacement effect of 7 percentage point increase in property crimes in the host community.

These findings show how crucial it is to distinguish between the different channels though which certain events may impact on criminal behaviour. In our case, how important is the effect on crime of the incapacitation of the potential thieves attending a match relative to the displacement of police to the stadium. These results will also fuel the ongoing public policy debate about who should 'pay for police' during football matches in the $\mathrm{UK}^{12}$. They do not however clearly answer this question since reduced property crime levels during away games could be seen as socially beneficial although one could argue that it is only displacing the cost to other communities. More importantly, the surprising result of no changes in violent behaviour during matches - except during derbies where the emotional state of fans is arguably the 'hottest' - suggests that the high levels of police deployed is successful in containing group violence behaviour. Indeed, recent research by Poutvaara and Priks (2009) has shown that removal of officers in charge of the monitoring of sports fan leads to sharp increases in hooligan violence. One could therefore conclude to some social benefits of the police being displaced to stadiums although this should of course not be at the cost to the rest of the community.

\footnotetext{
12 "Football 'should pay for police’”, BBC News Online, $12^{\text {th }}$ August 2008, http://news.bbc.co.uk/2/hi/uk news/7553875.stm
} 


\section{References}

Bloom, Nicholas (2007) “The Impact of Uncertainty Shocks,” Econometrica, 77, 623685.

Card, David and Gordon Dahl (2009) "Family Violence and Football: The Effect of Unexpected Emotional Cues on Violent Behavior” NBER Working Paper No. 15497

Dahl, Gordon and Stefano DellaVigna (2009) “Does Movie Violence Increase Violent Crime?” Quarterly Journal of Economics, 124, 677-734.

Di Tella, Rafael and Ernesto Schargrodsky (2004) “Do Police Reduce Crime? Estimate Using the Allocation of Police Forces after a Terrorist Attack.” American Economic Review, 94, 115-133.

Draca, Mirco, Stephen Machin, and Rober Witt (2008) "Panic on the Streets of London: Police, Crime and the July 2005 Terror Attack,” CEP Discussion Paper No. 852

Dunning, Eric, Patrick Murphy, and John Williams (1988) The Roots of Football Hooliganism. A Historical and Sociological Study, London, Routledge and Kegan Paul

Hansen, Kisrtine (2003) “Education and the Crime-Age Profile” The British Journal of Criminology, 43, 141-168

Hausman, Jerry; Hall, Bronwyn H. and Griliches, Zvi. "Econometric Models for Count Data with an Application to the Patents-R\&D Relationship," Econometrica, 1984, 52, 909-938

Hirschi, Travis and Michael Gottfredson (1983) “Age and the Explanation of Crime,” American Journal of Sociology, 89, 552-584.

House of Commons Home Affairs Committee (2009) "The Cost of Policing Football Matches”, HC 676, London: The Stationary Office Ltd

Jacob, Brian and Lars Lefgren (2003) “Are Idle Hands the Devil's Workshop? Incapacitation, Concentration and Juvenile Crime," American Economic Review, 93, 1560-1577.

Jacob, Brian, Lars Lefgren, and Enrico Moretti (2007) “The Dynamics of Criminal Behaviour: Evidence from Weather Shocks,” Journal of Human Resources, 42, 489-527. 
Loewenstein, George (2000) "Emotions in Economic Theory and Economic Behaviour," The American Economic Review: Papers and Proceedings, 90, 426-432

Metropolitan Police Authority (2003) “Football Club Recharges” MPA Report 08 http://www.mpa.gov.uk/committees/x-f/2003/030116/08/

Poutvaara, Panu and Mikael Priks (2006) “The Effect of Police Intelligence on Group Violence: Evidence from Reassignments in Sweden," Journal of Public Economics, 93, 403-411

Rees, Daniel I. and Kevin T. Schnepel (2009) “College Football Games and Crime,” Journal of Sports Psychology, 10, 68-97

Williams, J. (Various Years) "FA Premier League Fan Survey: a national survey of FA Premier League club fans, General Sample Report,” Sir Norman Chester Centre for Football Research

Young, Kevin (2002) “Sport and Violence” in Jay Coakley and Eric Dunning, Eds. Handbook of Sports Studies, London, Sage Publications 
Figure 1: Potential Direction of Displacement, Incapacitation, and Concentration Effects on Property and Violent Crimes of Home and Away Games

\begin{tabular}{|l|c|c|c|c|}
\hline \multirow{2}{*}{} & \multicolumn{2}{|c|}{ Property } & \multicolumn{2}{c|}{ Violent } \\
\cline { 2 - 5 } & Home & Away & Home & Away \\
\hline Displacement & $\uparrow$ & $\rightarrow$ & $\uparrow$ & $\rightarrow$ \\
\hline Incapacitation & $\downarrow$ & $\downarrow$ & $\downarrow$ & $\downarrow$ \\
\hline Concentration & $\longrightarrow$ & $\rightarrow$ & $\uparrow$ & $\longrightarrow$ \\
\hline
\end{tabular}

Note: Upward and downward pointing arrows represent respectively positive and negative impact from each of the three channels - concentration, incapacitation, displacement- through which home or away sporting events may impact one local property or violent crime. The flat arrows suggest that we do not expect any effect during home or away games for the corresponding crime category. 
Figure 2: Map of London Boroughs

with Football Grounds and Associated Football Teams

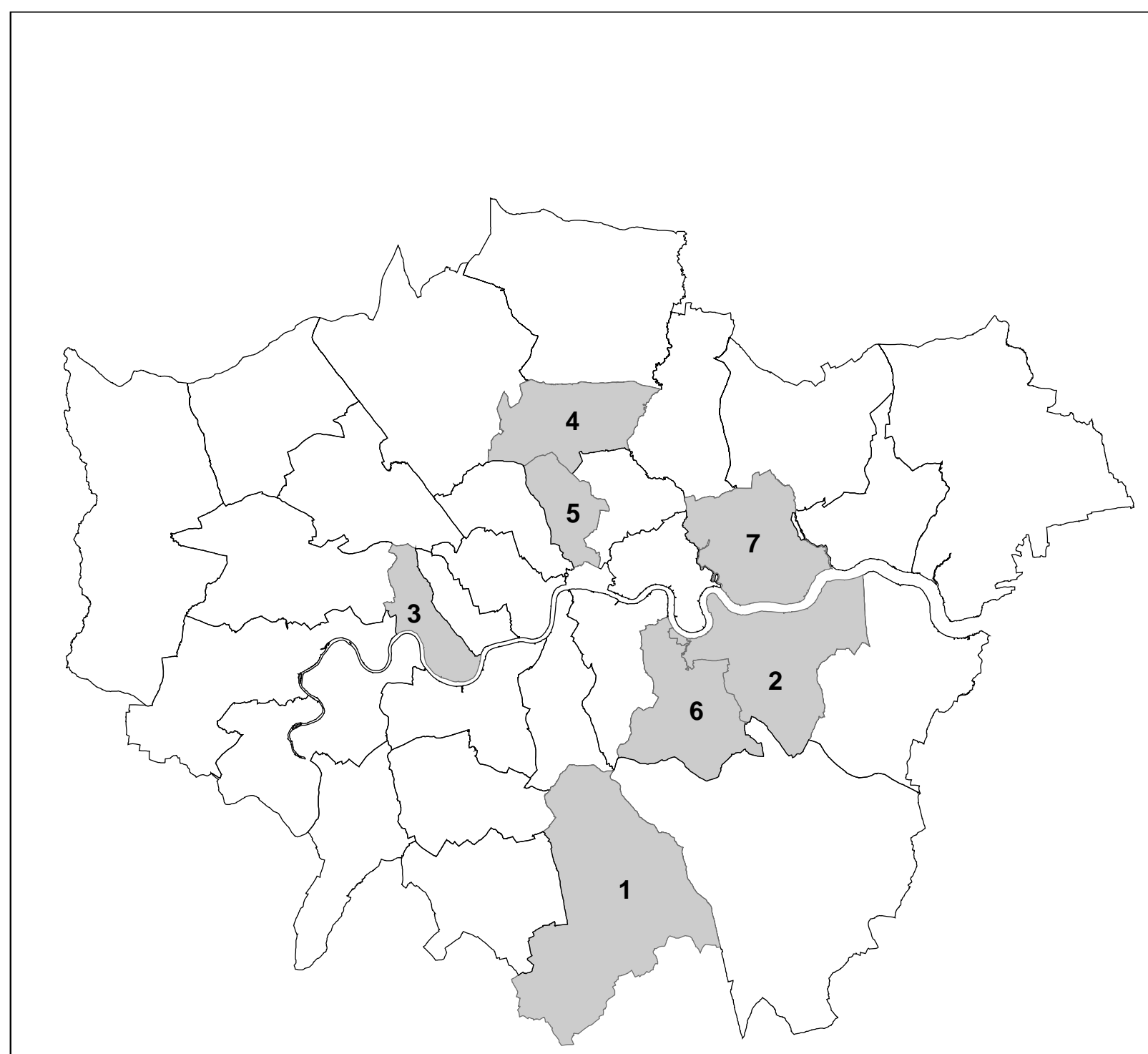

Borough

Team(s)

\begin{tabular}{|l|ll}
\hline 1 & Croydon & Crystal Palace \& Wimbledon \\
\hline 2 & Greenwich & Charlton Athletics \\
\hline 3 & Hammersmith \& Fulham & QPR \& Chelsea United \\
\hline 4 & Haringey & Tottenham Hotspur \\
\hline 5 & Islington & Arsenal \\
\hline 6 & Lewisham & Millwall \\
\hline 7 & Newham & West Ham United \\
\hline
\end{tabular}


Figure 3: Home and Away Attendance Levels Per Football Team
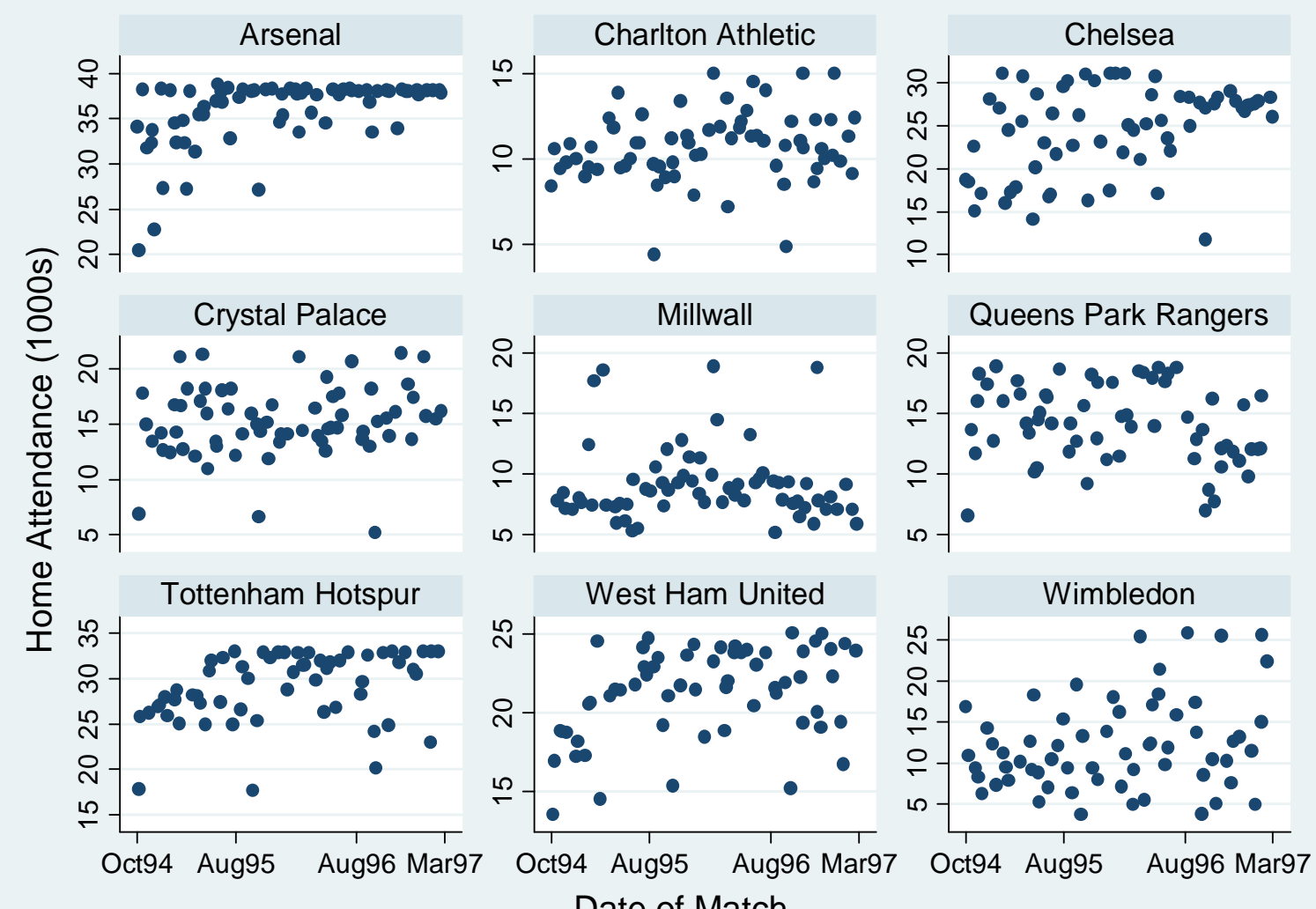

Date of Match

Arsenal

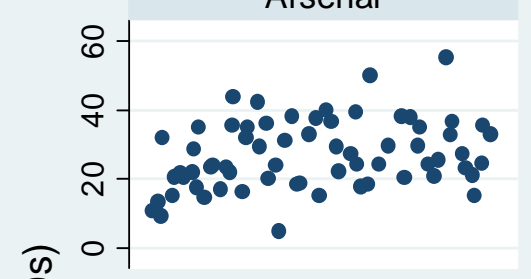

Crystal Palace

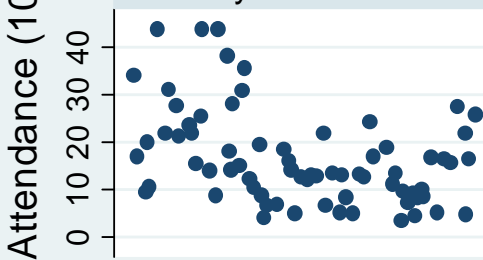

交

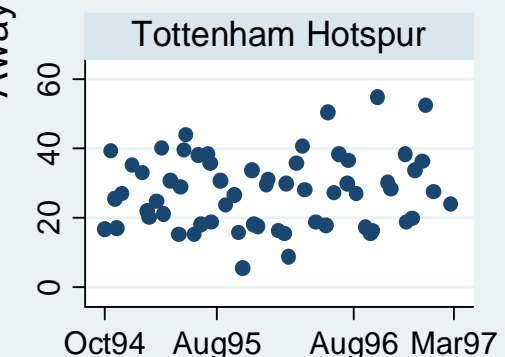

Charlton Athletic

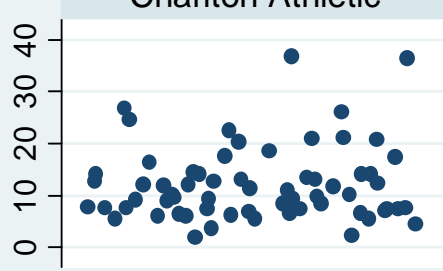

Millwall

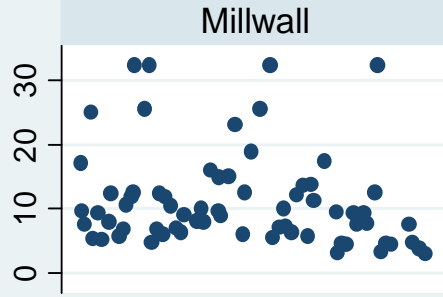

West Ham United

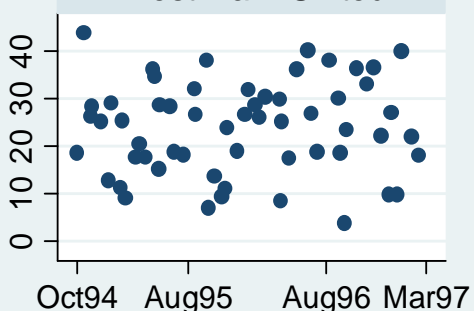

Date of Match
Chelsea
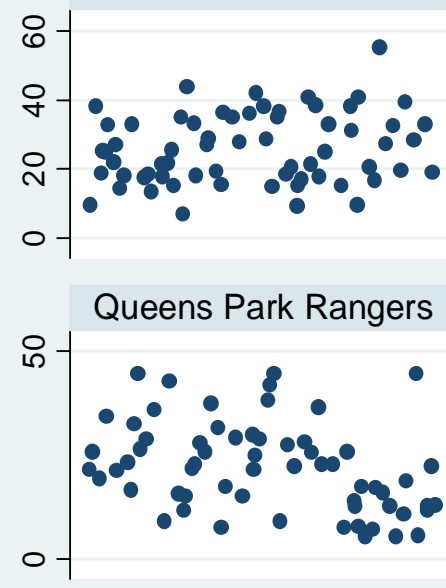

Wimbledon

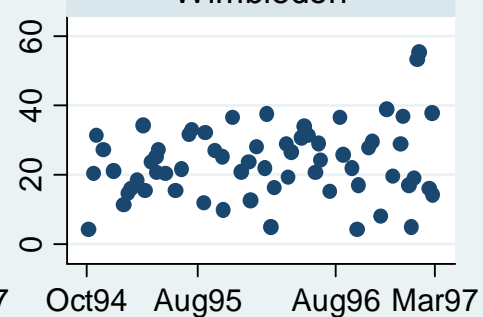

Oct94 Aug95 Aug96 Mar97 
Figures 4.1: Property Crime - Difference in Home and Away Attendance Impact Coefficients 12 Periods Before and After Game

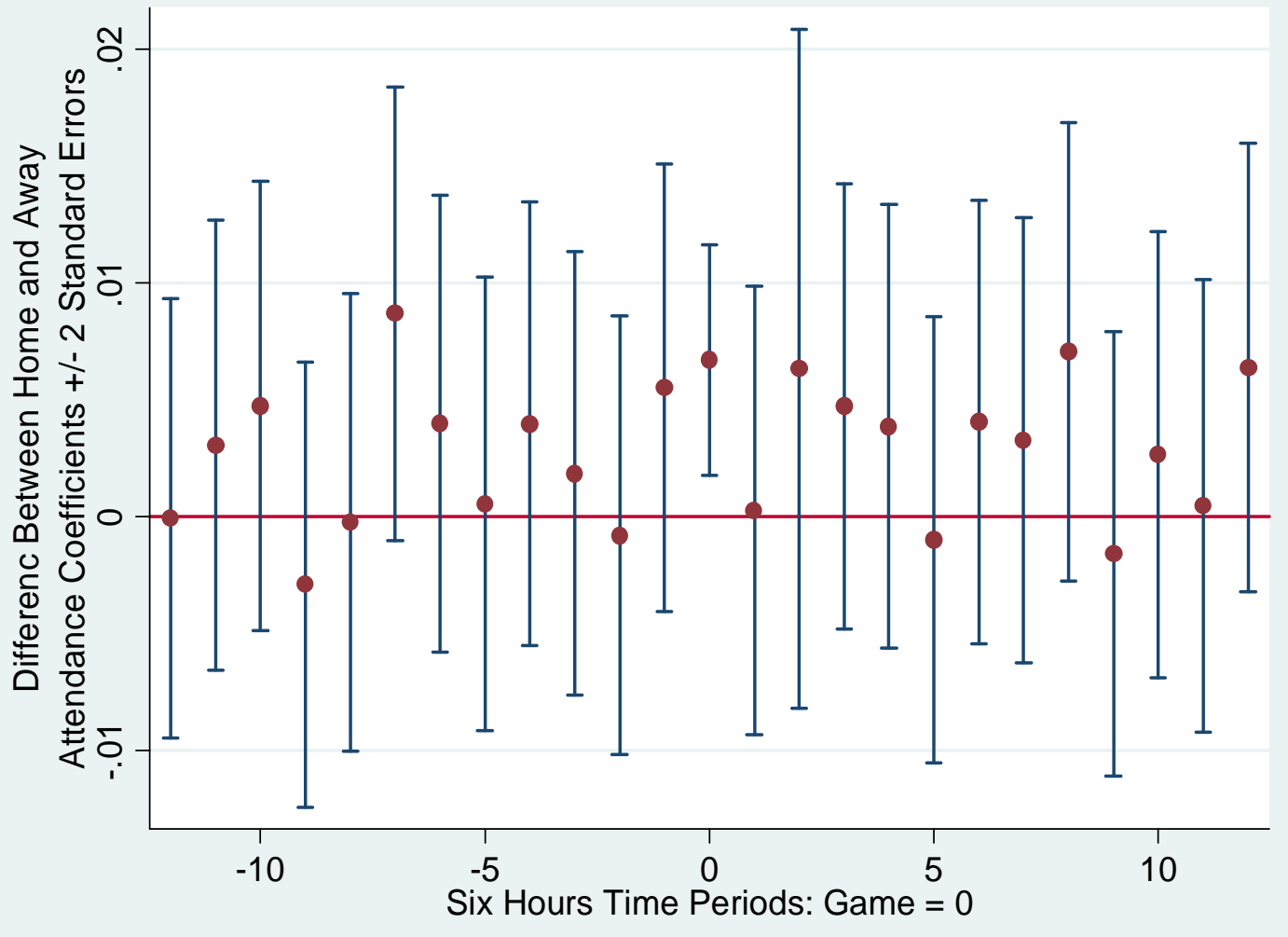

Figures 4.2: Violent Crime - Difference in Home and Away Attendance Impact Coefficients 12 Periods Before and After Game

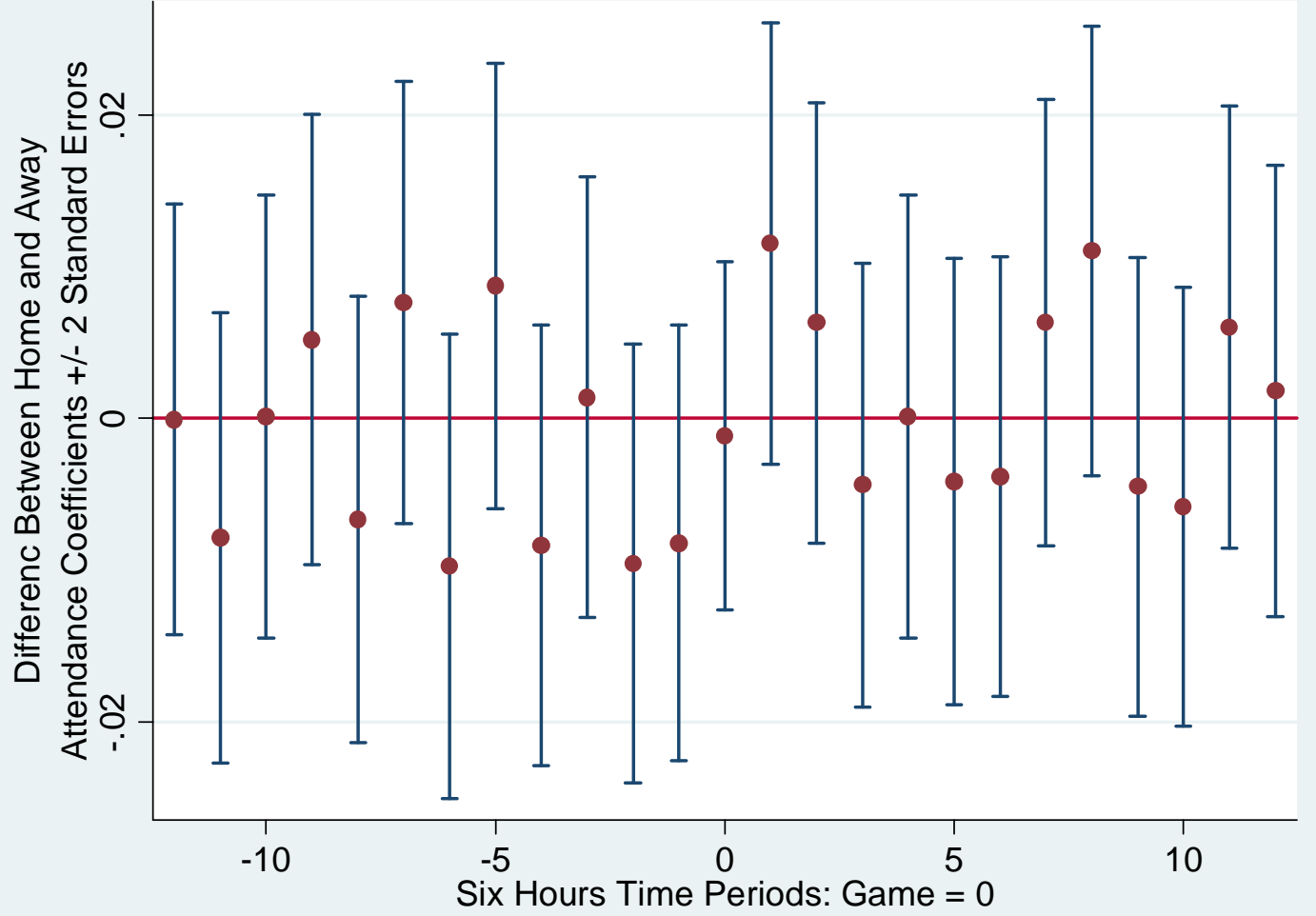


Table 1: Summary Statistics of Football Matches

\begin{tabular}{lcc}
\hline & $\begin{array}{c}\text { Number of } \\
\text { Games }\end{array}$ & $\begin{array}{c}\text { Fraction } \\
\text { of Games }\end{array}$ \\
\hline All Games & 1147 & 1 \\
Home Games & 571 & .502 \\
Away Games & 576 & .499 \\
London Derbies & 81 & .071 \\
Competitions & 98 & .172 \\
Upset Losses & 53 & .046 \\
Saturdays (12-18h) & 616 & .537 \\
Sunday (12-18h) & 107 & .093 \\
Other Days (12-18h) & 60 & .052 \\
Wednesday (18-00h) & 193 & .168 \\
Tuesday (18-00h) & 114 & .099 \\
Other Days (18-00h) & 57 & .050 \\
Croydon & 263 & .229 \\
Greenwich & 131 & .114 \\
Hammersmith & 247 & .215 \\
Haringey & 121 & .106 \\
Islington & 134 & 117 \\
Lewisham & 134 & .117 \\
Newham & 117 & .102 \\
\hline
\end{tabular}

Note: Summary statistics for the 1147 games played by the 9 London teams between October 1994 and March 1997. Upset losses are defined as the home team losing at a home or away game although the advantage in terms of Elo ratings was $>100$. 
$\underline{\text { Table } 2 \text { - Mean Number of Crimes per Hour Window }}$

\begin{tabular}{|c|c|c|c|c|c|c|}
\hline & \multicolumn{6}{|c|}{$\begin{array}{l}\text { Mean Number of Crimes } \\
\text { (Standard Deviations) }\end{array}$} \\
\hline & \multicolumn{3}{|c|}{12 to 18 Hours } & \multicolumn{3}{|c|}{18 to 00 Hours } \\
\hline & $\begin{array}{l}\text { No } \\
\text { Game }\end{array}$ & $\begin{array}{l}\text { Home } \\
\text { Game }\end{array}$ & $\begin{array}{l}\text { Away } \\
\text { Game }\end{array}$ & $\begin{array}{l}\text { No } \\
\text { Game }\end{array}$ & $\begin{array}{l}\text { Home } \\
\text { Game }\end{array}$ & $\begin{array}{l}\text { Away } \\
\text { Game }\end{array}$ \\
\hline All Crimes & $\begin{array}{l}29.48 \\
(11.81)\end{array}$ & $\begin{array}{c}30.99 \\
(13.85)\end{array}$ & $\begin{array}{l}29.13 \\
(13.24)\end{array}$ & $\begin{array}{l}20.37 \\
(8.76)\end{array}$ & $\begin{array}{l}21.83 \\
(8.93)\end{array}$ & $\begin{array}{l}20.13 \\
(9.68)\end{array}$ \\
\hline Property Crimes & $\begin{array}{l}20.94 \\
(8.85)\end{array}$ & $\begin{array}{c}23.70 \\
(11.04)\end{array}$ & $\begin{array}{l}21.60 \\
(10.61)\end{array}$ & $\begin{array}{l}12.06 \\
(5.55)\end{array}$ & $\begin{array}{l}14.36 \\
(5.76)\end{array}$ & $\begin{array}{l}12.45 \\
(5.63)\end{array}$ \\
\hline Burglaries & $\begin{array}{c}6.48 \\
(4.07)\end{array}$ & $\begin{array}{c}6.65 \\
(4.41)\end{array}$ & $\begin{array}{c}6.52 \\
(4.08)\end{array}$ & $\begin{array}{c}4.16 \\
(3.06)\end{array}$ & $\begin{array}{c}3.85 \\
(2.59)\end{array}$ & $\begin{array}{c}3.82 \\
(2.89)\end{array}$ \\
\hline Thefts & $\begin{array}{l}14.25 \\
(6.69)\end{array}$ & $\begin{array}{l}16.79 \\
(8.61)\end{array}$ & $\begin{array}{l}14.89 \\
(8.33)\end{array}$ & $\begin{array}{c}7.65 \\
(3.98)\end{array}$ & $\begin{array}{l}10.27 \\
(4.58)\end{array}$ & $\begin{array}{c}8.41 \\
(3.93)\end{array}$ \\
\hline Criminal Damage & $\begin{array}{c}0.20 \\
(0.57)\end{array}$ & $\begin{array}{c}0.26 \\
(0.74)\end{array}$ & $\begin{array}{c}0.18 \\
(0.48)\end{array}$ & $\begin{array}{c}0.24 \\
(0.61)\end{array}$ & $\begin{array}{c}0.25 \\
(0.51)\end{array}$ & $\begin{array}{c}0.23 \\
(0.54)\end{array}$ \\
\hline Violent Crimes & $\begin{array}{c}7.40 \\
(5.56)\end{array}$ & $\begin{array}{c}6.28 \\
(5.22)\end{array}$ & $\begin{array}{c}6.63 \\
(5.64)\end{array}$ & $\begin{array}{c}7.15 \\
(5.37)\end{array}$ & $\begin{array}{c}6.35 \\
(5.10)\end{array}$ & $\begin{array}{c}6.86 \\
(5.90)\end{array}$ \\
\hline Violence & $\begin{array}{c}3.86 \\
(3.97)\end{array}$ & $\begin{array}{c}3.72 \\
(3.77)\end{array}$ & $\begin{array}{c}3.82 \\
(4.17)\end{array}$ & $\begin{array}{c}4.26 \\
(4.32)\end{array}$ & $\begin{array}{c}3.90 \\
(4.00)\end{array}$ & $\begin{array}{c}4.18 \\
(4.21)\end{array}$ \\
\hline Sexual offences & $\begin{array}{c}0.34 \\
(1.09)\end{array}$ & $\begin{array}{c}0.24 \\
(0.84)\end{array}$ & $\begin{array}{c}0.22 \\
(0.81)\end{array}$ & $\begin{array}{c}0.30 \\
(0.97)\end{array}$ & $\begin{array}{c}0.19 \\
(0.74)\end{array}$ & $\begin{array}{c}0.27 \\
(0.97)\end{array}$ \\
\hline Robberies & $\begin{array}{c}3.20 \\
(1.17)\end{array}$ & $\begin{array}{c}2.32 \\
(3.04)\end{array}$ & $\begin{array}{c}2.59 \\
(3.34)\end{array}$ & $\begin{array}{c}2.59 \\
(2.96)\end{array}$ & $\begin{array}{c}2.26 \\
(3.13)\end{array}$ & $\begin{array}{c}2.41 \\
(3.27)\end{array}$ \\
\hline Sample & 5,007 & 391 & 392 & 5,315 & 180 & 184 \\
\hline
\end{tabular}

Note: The reported means are generated from the 7 boroughs which are home to one of the 9 teams since there are no equivalent for the home and away columns for the other boroughs. 
Table 3: Impact of Home and Away Games and Attendance Levels on Total Number, Property, and Violent Crimes Reported to the Police

\begin{tabular}{|c|c|c|c|c|c|c|}
\hline & & & $\begin{array}{l}\text { epender } \\
\text { nber of }\end{array}$ & $\begin{array}{l}\text { Variable } \\
\text { imes Rep }\end{array}$ & $\begin{array}{l}= \\
\text { rted }\end{array}$ & \\
\hline & & All & imes & & Property & Violent \\
\hline & (1) & (2) & (3) & (4) & (5) & (6) \\
\hline Home Game Dummy & $\begin{array}{l}.009 \\
(.033)\end{array}$ & $\begin{array}{l}.054^{*} \\
(.033)\end{array}$ & $\begin{array}{l}.086^{* *} \\
(.040)\end{array}$ & $\begin{array}{l}.084^{* *} \\
(.040)\end{array}$ & $\begin{array}{c}.136 * * * \\
(.041)\end{array}$ & $\begin{array}{l}.104 \\
(.095)\end{array}$ \\
\hline $\begin{array}{l}\text { Home Game Attendance } \\
\text { (in Thousands) }\end{array}$ & $\begin{array}{l}.003^{*} \\
(.002)\end{array}$ & $\begin{array}{l}.003^{*} \\
(.002)\end{array}$ & $\begin{array}{l}.004^{* *} \\
(.002)\end{array}$ & $\begin{array}{l}.004^{* *} \\
(.002)\end{array}$ & $\begin{array}{l}.004 * * \\
(.002)\end{array}$ & $\begin{array}{l}.002 \\
(.004)\end{array}$ \\
\hline Away Game Dummy & $\begin{array}{l}-.023 \\
(.031)\end{array}$ & $\begin{array}{l}.019 \\
(.032)\end{array}$ & $\begin{array}{l}-.008 \\
(.038)\end{array}$ & $\begin{array}{l}-.020 \\
(.042)\end{array}$ & $\begin{array}{l}-.011 \\
(.040)\end{array}$ & $\begin{array}{l}.055 \\
(.092)\end{array}$ \\
\hline $\begin{array}{l}\text { Away Game Attendance } \\
\text { (in Thousands) }\end{array}$ & $\begin{array}{l}-.000 \\
(.001)\end{array}$ & $\begin{array}{l}-.001 \\
(.001)\end{array}$ & $\begin{array}{l}-.001 \\
(.001)\end{array}$ & $\begin{array}{l}-.002 \\
(.002)\end{array}$ & $\begin{array}{c}-.004^{* *} \\
(.002)\end{array}$ & $\begin{array}{l}.002 \\
(.004)\end{array}$ \\
\hline $\begin{array}{l}\text { Dummy Number of Other } \\
\text { Home and Away Games }\end{array}$ & No & Yes & Yes & Yes & Yes & Yes \\
\hline $\begin{array}{l}\text { Attendance to Other Home } \\
\text { and Away Games }\end{array}$ & No & No & Yes & Yes & Yes & Yes \\
\hline $\begin{array}{l}\text { Distance from Borough of } \\
\text { Home and to Away Games }\end{array}$ & No & No & No & Yes & Yes & Yes \\
\hline Holiday Indicator & Yes & Yes & Yes & Yes & Yes & Yes \\
\hline Rain and Temperature & Yes & Yes & Yes & Yes & Yes & Yes \\
\hline $\begin{array}{l}\text { Borough * Hour * Day of } \\
\text { the Week * Month * Season } \\
\text { Fixed Effects }\end{array}$ & Yes & Yes & Yes & Yes & Yes & Yes \\
\hline Observations & 43,896 & 43,896 & 43,896 & 43,896 & 43,896 & 43,896 \\
\hline
\end{tabular}

Notes: An observation is a six hour period 12 to $18 \mathrm{H}$ or 18 to $00 \mathrm{H}$ for the 31 London boroughs during the football season (mid -August to mid-May) between September 1994 and October 1997. The estimates come from negative binomial regressions, standard errors are in parenthesis. $*, * *$, and ${ }^{* * *}$ respectively denote significance at the 10, 5, and 1 percent level. 
Table 4: Impact of Home and Away Games and Attendance Levels on Various Types of Crimes Reported to the Police

\begin{tabular}{|c|c|c|c|c|c|c|}
\hline & Num & er of Crim & $\begin{array}{l}\text { Sependent } \\
\text { s Reported }\end{array}$ & $\begin{array}{l}\text { ariables }= \\
\text { or the Foll }\end{array}$ & ving Cat & ories \\
\hline & & operty Cri & & & Violent & \\
\hline & Theft & Burglary & $\begin{array}{l}\text { Criminal } \\
\text { Damage } \\
\end{array}$ & Violence & Sexual & Robbery \\
\hline Home Game Dummy & $\begin{array}{c}.192^{* * *} \\
(.046)\end{array}$ & $\begin{array}{l}.026 \\
(.073)\end{array}$ & $\begin{array}{l}.124 \\
(.263)\end{array}$ & $\begin{array}{l}.203^{*} \\
(.121)\end{array}$ & $\begin{array}{l}-.517 \\
(.428)\end{array}$ & $\begin{array}{l}.183 \\
(.145)\end{array}$ \\
\hline $\begin{array}{l}\text { Home Game Attendance } \\
\text { (in Thousands) }\end{array}$ & $\begin{array}{c}.006^{* * *} \\
(.002)\end{array}$ & $\begin{array}{l}-.001 \\
(.003)\end{array}$ & $\begin{array}{l}.002 \\
(.011)\end{array}$ & $\begin{array}{l}.001 \\
(.005)\end{array}$ & $\begin{array}{l}.006 \\
(.017)\end{array}$ & $\begin{array}{l}-.008 \\
(.006)\end{array}$ \\
\hline Away Game Dummy & $\begin{array}{l}.040 \\
(.050)\end{array}$ & $\begin{array}{l}-.102 \\
(.074)\end{array}$ & $\begin{array}{l}.168 \\
(.290)\end{array}$ & $\begin{array}{l}.133 \\
(.119)\end{array}$ & $\begin{array}{l}-.263 \\
(.418)\end{array}$ & $\begin{array}{l}.005 \\
(.139)\end{array}$ \\
\hline $\begin{array}{l}\text { Away Game Attendance } \\
\text { (in Thousands) }\end{array}$ & $\begin{array}{c}-.006^{* * *} \\
(.002)\end{array}$ & $\begin{array}{l}.002 \\
(.003)\end{array}$ & $\begin{array}{l}-.015 \\
(.012)\end{array}$ & $\begin{array}{l}.005 \\
(.005)\end{array}$ & $\begin{array}{l}-.020 \\
(.015)\end{array}$ & $\begin{array}{l}.003 \\
(.005)\end{array}$ \\
\hline $\begin{array}{l}\text { Dummy Number of Other } \\
\text { Home and Away Games }\end{array}$ & Yes & Yes & Yes & Yes & Yes & Yes \\
\hline $\begin{array}{l}\text { Attendance to Other Home } \\
\text { and Away Games }\end{array}$ & Yes & Yes & Yes & Yes & Yes & Yes \\
\hline $\begin{array}{l}\text { Distance from Borough of } \\
\text { Home and to Away Games }\end{array}$ & Yes & Yes & Yes & Yes & Yes & Yes \\
\hline Holiday Indicator & Yes & Yes & Yes & Yes & Yes & Yes \\
\hline Rain and Temperature & Yes & Yes & Yes & Yes & Yes & Yes \\
\hline $\begin{array}{l}\text { Borough * Hour * Day of } \\
\text { the Week * Month * } \\
\text { Season Fixed Effects }\end{array}$ & Yes & Yes & Yes & Yes & Yes & Yes \\
\hline Observations & 43,896 & 43,896 & 43,896 & 43,896 & 43,896 & 43,896 \\
\hline
\end{tabular}

Notes: An observation is a six hour period 12 to $18 \mathrm{H}$ or 18 to $00 \mathrm{H}$ for the 31 London boroughs during the football season (mid -August to mid-May) between September 1994 and October 1997. The estimates come from negative binomial regressions, standard errors in parenthesis. ${ }^{*}, * *$, and ${ }^{* * *}$ respectively denote significance at the 10,5 , and 1 percent level. 
Table 5: Impact on Property and Violent Crime of Home and Away Games and Attendance Levels Controlling for Match Characteristics

\begin{tabular}{|c|c|c|c|c|}
\hline & \multicolumn{4}{|c|}{$\begin{array}{c}\text { Dependent Variables }= \\
\text { Number of Crimes Reported }\end{array}$} \\
\hline & \multicolumn{2}{|c|}{ Property Crime } & \multicolumn{2}{|c|}{ Violent } \\
\hline & Home & Away & Home & Away \\
\hline Game Dummy & $\begin{array}{l}.139 * * * \\
(.042)\end{array}$ & $\begin{array}{l}.014 \\
(.047)\end{array}$ & $\begin{array}{l}.126 \\
(.097)\end{array}$ & $\begin{array}{l}.013 \\
(.097)\end{array}$ \\
\hline Game Attendance & $\begin{array}{l}.004^{* *} \\
(.002)\end{array}$ & $\begin{array}{l}-.003^{*} \\
(.002)\end{array}$ & $\begin{array}{l}.001 \\
(.005)\end{array}$ & $\begin{array}{l}.002 \\
(.004)\end{array}$ \\
\hline Lose Game Upset & $\begin{array}{l}-.019 \\
(.079)\end{array}$ & $\begin{array}{l}-.087 \\
(.091)\end{array}$ & $\begin{array}{l}.127 \\
(.211)\end{array}$ & $\begin{array}{l}-.050 \\
(.231)\end{array}$ \\
\hline Goal Difference & $\begin{array}{l}.015 \\
(.019)\end{array}$ & $\begin{array}{l}-.000 \\
(.021)\end{array}$ & $\begin{array}{l}-.052 \\
(.051)\end{array}$ & $\begin{array}{l}-.023 \\
(.052)\end{array}$ \\
\hline Number of Cards & $\begin{array}{l}-.002 \\
(.008)\end{array}$ & $\begin{array}{l}-.008 \\
(.012)\end{array}$ & $\begin{array}{l}.005 \\
(.018)\end{array}$ & $\begin{array}{l}-.026 \\
(.031)\end{array}$ \\
\hline London Derby & $\begin{array}{l}-.005 \\
(.042)\end{array}$ & $\begin{array}{l}-.069 \\
(.052)\end{array}$ & $\begin{array}{l}.184^{*} \\
(.100)\end{array}$ & $\begin{array}{l}.168 \\
(.114)\end{array}$ \\
\hline Competition Round & $\begin{array}{l}-.001 \\
(.012)\end{array}$ & $\begin{array}{l}-.016 \\
(.012)\end{array}$ & $\begin{array}{l}-.035 \\
(.030)\end{array}$ & $\begin{array}{l}-.015 \\
(.025)\end{array}$ \\
\hline $\begin{array}{l}\text { Dummy Number of Other } \\
\text { Home and Away Games }\end{array}$ & \multicolumn{2}{|c|}{ Yes } & \multicolumn{2}{|c|}{ Yes } \\
\hline $\begin{array}{l}\text { Attendance to Other Home } \\
\text { and Away Games }\end{array}$ & \multicolumn{2}{|c|}{ Yes } & \multicolumn{2}{|c|}{ Yes } \\
\hline $\begin{array}{l}\text { Distance from Borough of } \\
\text { Home and to Away Games }\end{array}$ & \multicolumn{2}{|c|}{ Yes } & \multicolumn{2}{|c|}{ Yes } \\
\hline Holiday Indicator & \multicolumn{2}{|c|}{ Yes } & \multicolumn{2}{|c|}{ Yes } \\
\hline Rain and Temperature & \multicolumn{2}{|c|}{ Yes } & \multicolumn{2}{|c|}{ Yes } \\
\hline $\begin{array}{l}\text { Borough * Hour * Day of } \\
\text { the Week * Month * } \\
\text { Season Fixed Effects }\end{array}$ & \multicolumn{2}{|c|}{ Yes } & \multicolumn{2}{|c|}{ Yes } \\
\hline Observations & \multicolumn{2}{|c|}{43,896} & \multicolumn{2}{|c|}{43,896} \\
\hline
\end{tabular}

Notes: An observation is a six hour period between 12 to $18 \mathrm{H}$ or 18 to $00 \mathrm{H}$ for the 31 London boroughs during the football season (mid -August to mid-May) between September 1994 and October 1997. The estimates come from negative binomial regressions, standard errors in parenthesis. *, **, and $* * *$ respectively denote significance at the 10,5 , and 1 percent level. 
Table 6.1: Time Displacement of Property Crime - Impact of Home and Away Games and Attendance Levels Controlling for Match Characteristics

\begin{tabular}{|c|c|c|c|c|}
\hline & \multicolumn{4}{|c|}{$\begin{array}{l}\text { Dependent Variables = } \\
\text { Number of Property Crimes Reported }\end{array}$} \\
\hline & \multicolumn{2}{|c|}{ Before } & \multicolumn{2}{|c|}{ After } \\
\hline & Home & Away & Home & Away \\
\hline Game Dummy & $\begin{array}{l}-.021 \\
(.081)\end{array}$ & $\begin{array}{l}.011 \\
(.086)\end{array}$ & $\begin{array}{l}-.007 \\
(.081)\end{array}$ & $\begin{array}{l}.006 \\
(.084)\end{array}$ \\
\hline Game Attendance & $\begin{array}{l}.002 \\
(.004)\end{array}$ & $\begin{array}{l}-.003 \\
(.003)\end{array}$ & $\begin{array}{l}.003 \\
(.004)\end{array}$ & $\begin{array}{l}-.001 \\
(.003)\end{array}$ \\
\hline Lose Game Upset & $\begin{array}{l}.074 \\
(.180)\end{array}$ & $\begin{array}{l}-.054 \\
(.183)\end{array}$ & $\begin{array}{l}.077 \\
(.187)\end{array}$ & $\begin{array}{l}.081 \\
(.172)\end{array}$ \\
\hline Goal Difference & $\begin{array}{l}-.031 \\
(.040)\end{array}$ & $\begin{array}{l}.019 \\
(.043)\end{array}$ & $\begin{array}{l}.054 \\
(.042)\end{array}$ & $\begin{array}{l}-.012 \\
(.045)\end{array}$ \\
\hline Number of Cards & $\begin{array}{l}.009 \\
(.015)\end{array}$ & $\begin{array}{l}-.009 \\
(.023)\end{array}$ & $\begin{array}{l}.018 \\
(.014)\end{array}$ & $\begin{array}{l}-.028 \\
(.021)\end{array}$ \\
\hline London Derby & $\begin{array}{l}-.061 \\
(.088)\end{array}$ & $\begin{array}{l}.038 \\
(.095)\end{array}$ & $\begin{array}{l}-.040 \\
(.086)\end{array}$ & $\begin{array}{l}.033 \\
(.097)\end{array}$ \\
\hline Competition Round & $\begin{array}{l}.012 \\
(.003)\end{array}$ & $\begin{array}{l}-.015 \\
(.021)\end{array}$ & $\begin{array}{l}.033 \\
(.022)\end{array}$ & $\begin{array}{c}-.004 \\
(.021)\end{array}$ \\
\hline $\begin{array}{l}\text { Dummy Number of Other } \\
\text { Home and Away Games }\end{array}$ & \multicolumn{2}{|c|}{ Yes } & \multicolumn{2}{|c|}{ Yes } \\
\hline $\begin{array}{l}\text { Attendance to Other Home } \\
\text { and Away Games }\end{array}$ & \multicolumn{2}{|c|}{ Yes } & \multicolumn{2}{|c|}{ Yes } \\
\hline $\begin{array}{l}\text { Distance from Borough of } \\
\text { Home and to Away Games }\end{array}$ & \multicolumn{2}{|c|}{ Yes } & \multicolumn{2}{|c|}{ Yes } \\
\hline Holiday Indicator & \multicolumn{2}{|c|}{ Yes } & \multicolumn{2}{|c|}{ Yes } \\
\hline Rain and Temperature & \multicolumn{2}{|c|}{ Yes } & \multicolumn{2}{|c|}{ Yes } \\
\hline $\begin{array}{l}\text { Borough * Hour * Day of } \\
\text { the Week * Month * Season } \\
\text { Fixed Effects }\end{array}$ & \multicolumn{2}{|c|}{ Yes } & \multicolumn{2}{|c|}{ Yes } \\
\hline Observations & \multicolumn{2}{|c|}{43,880} & \multicolumn{2}{|c|}{43,880} \\
\hline
\end{tabular}

Notes: An observation is a six hour period before and after 12 to $18 \mathrm{H}$ or 18 to $00 \mathrm{H}$ depending on the time the game started for the 31 London boroughs during the football season (mid -August to mid-May) between September 1994 and October 1997. The estimates come from negative binomial regressions, standard errors in parenthesis. *, **, and *** respectively denote significance at the 10,5 , and 1 percent level. 
Table 6.2: Time Displacement of Violent Crime - Impact of Home and Away Games and Attendance Levels Controlling for Match Characteristics

\begin{tabular}{|c|c|c|c|c|}
\hline & \multicolumn{4}{|c|}{$\begin{array}{l}\text { Dependent Variables }= \\
\text { Number of Violent Crimes Reported }\end{array}$} \\
\hline & \multicolumn{2}{|c|}{ Before } & \multicolumn{2}{|c|}{ After } \\
\hline & Home & Away & Home & Away \\
\hline Game Dummy & $\begin{array}{l}.108 \\
(.123)\end{array}$ & $\begin{array}{l}-.065 \\
(.126)\end{array}$ & $\begin{array}{l}-.008 \\
(.121)\end{array}$ & $\begin{array}{l}.107 \\
(.131)\end{array}$ \\
\hline Game Attendance & $\begin{array}{l}.009 \\
(.006)\end{array}$ & $\begin{array}{l}.004 \\
(.005)\end{array}$ & $\begin{array}{l}.010^{*} \\
(.006)\end{array}$ & $\begin{array}{l}-.002 \\
(.005)\end{array}$ \\
\hline Lose Game Upset & $\begin{array}{l}-.334 \\
(.296)\end{array}$ & $\begin{array}{l}-.365 \\
(.329)\end{array}$ & $\begin{array}{l}.030 \\
(.267)\end{array}$ & $\begin{array}{l}-.291 \\
(.278)\end{array}$ \\
\hline Goal Difference & $\begin{array}{l}-.073 \\
(.070)\end{array}$ & $\begin{array}{l}-.014 \\
(.069)\end{array}$ & $\begin{array}{l}.072 \\
(.056)\end{array}$ & $\begin{array}{l}-.046 \\
(.066)\end{array}$ \\
\hline Number of Cards & $\begin{array}{l}-.034 \\
(.024)\end{array}$ & $\begin{array}{l}-.023 \\
(.040)\end{array}$ & $\begin{array}{l}-.026 \\
(.023)\end{array}$ & $\begin{array}{l}-.018 \\
(.034)\end{array}$ \\
\hline London Derby & $\begin{array}{l}-.199 \\
(.143)\end{array}$ & $\begin{array}{l}.017 \\
(.145)\end{array}$ & $\begin{array}{l}-.158 \\
(.132)\end{array}$ & $\begin{array}{l}.029 \\
(.141)\end{array}$ \\
\hline Competition Round & $\begin{array}{l}-.021 \\
(.034)\end{array}$ & $\begin{array}{l}-.015 \\
(.031)\end{array}$ & $\begin{array}{l}-.021 \\
(.034)\end{array}$ & $\begin{array}{c}-.012 \\
(.032)\end{array}$ \\
\hline $\begin{array}{l}\text { Dummy Number of Other } \\
\text { Home and Away }\end{array}$ & \multicolumn{2}{|c|}{ Yes } & \multicolumn{2}{|c|}{ Yes } \\
\hline $\begin{array}{l}\text { Attendance to Other Home } \\
\text { and Away }\end{array}$ & \multicolumn{2}{|c|}{ Yes } & \multicolumn{2}{|c|}{ Yes } \\
\hline $\begin{array}{l}\text { Distance from Home Game } \\
\text { Borough }\end{array}$ & \multicolumn{2}{|c|}{ Yes } & \multicolumn{2}{|c|}{ Yes } \\
\hline Holiday Indicator & \multicolumn{2}{|c|}{ Yes } & \multicolumn{2}{|c|}{ Yes } \\
\hline Rain and Temperature & \multicolumn{2}{|c|}{ Yes } & \multicolumn{2}{|c|}{ Yes } \\
\hline $\begin{array}{l}\text { Borough * Hour * Day of } \\
\text { the Week * Month * Year } \\
\text { Fixed Effects }\end{array}$ & \multicolumn{2}{|c|}{ Yes } & \multicolumn{2}{|c|}{ Yes } \\
\hline Observations & \multicolumn{2}{|c|}{43,880} & \multicolumn{2}{|c|}{43,880} \\
\hline
\end{tabular}

Notes: An observation is a six hour period before and after 12 P.M. to 6 P.M. or 6 P.M. to 12 A.M depending on the time the game started for the 31 London boroughs during the football season (mid -August to mid-May) between September 1994 and October 1997. The estimates come from negative binomial regressions, standard errors in parenthesis. ${ }^{*}$, **, and *** respectively denote significance at the 10,5 , and 1 percent level. 